\title{
GROWTH ANALYSIS OF BRRI DHAN-44 (ORYZA SATIVA L.) FOLLOWING 2,3,5 TRI-IODO BENZOIC ACID APPLICATION
}

\author{
A. M.M. GOLAM ADAM, ${ }^{1}$ RASEDUL ISLAM, \\ HASNA HENA BEGUM AND KAMRUN NAHER \\ Department of Botany, Jagannath University, Dhaka-1100, Bangladesh
}

\begin{abstract}
A pot experiment was conducted to investigate the effect of different concentrations $(0$, $10,25,50$ and $100 \mathrm{ppm}$ ) of 2,3,5 Tri-iodo benzoic acid (TIBA) on growth of BRRI dhan44. With few exceptions LA, LAR, SLA and LAD showed almost similar trend and increased due to $10 \mathrm{ppm}$ at all stages. Whereas, other treatments showed a decrease in most cases. Significant variations were observed at 40 DAS in LA, at 20 and 40 DAS in LAR and throughout the growing period of SLA and LAD. Significant increase was observed in SLW at concentration higher than $10 \mathrm{ppm}$ TIBA. Plants treated with $25 \mathrm{ppm}$ TIBA produced the highest SLW after 10 DAS. Maximum NAR was also recorded from $25 \mathrm{ppm}$ at all phases of growth and varied significantly at 20-30 DAS. Application of TIBA had positive response on CGR in the majority cases and significant variation was observed at the period of 0-10 and 50-60 DAS. The RGR responded similarly like CGR, but varied significantly in all cases except at 10-20 DAS. After the period of 20-30 DAS, BMD were found to increase following all treatments excluding $50 \mathrm{ppm}$ and significant variations were observed all over the growing period. Out of five treatments, $10 \mathrm{ppm}$ TIBA showed better responses in the majority of growth parameters.
\end{abstract}

Key words: BRRI dhan-44, TIBA, Foliar application, Growth analysis

\section{Introduction}

There are several yield boosting agronomic techniques where, application of certain plant growth regulators needs due attention. These substances so far have emerged as "magic chemicals" that could increase agricultural production at an unprecedented rate and help in removing and circumventing many of the barriers imposed by genetics and environment. Deficiency of growth regulators at any stage of plant growth may also creates a barrier in attaining maximum growth and yield.

Plant growth analysis is considered to be a standard approach to study growth and productivity (Wilson 1981). Among the wide range of growth regulating substances, 2,3,5 Tri-iodo benzoic acid (TIBA), although known as growth retardant but, become very much effective at low concentration in modifying plant growth and development. Researchers of the world showed that appropriate concentration of TIBA induce various growth parameters and yield of different economically important plants viz. soybean (Ravichandran and Ramaswami 1991), okra (Surendra et al. 2006), bottle gourd

${ }^{1}$ Corresponding author: E-mail: adam_du04@yahoo.com 
(Rahman and Rahman 1997), groundnut (Kler and Dhillon 1993), tomato (Mondal and Dutta 2002), jatropha (Abdelgadir et al. 2009), alfalfa (Phillips and Chilcote 1981), cotton (Djanaguiraman et al. 2005).

Since there are very little information about the effect of TIBA on growth parameters of any cereals crops from elsewhere of the world and also in Bangladesh, the present work was undertaken to evaluate the effect of TIBA on different growth parameters and yield of BRRI dhan-44.

\section{Materials and Methods}

A pot experiment was carried out at the research Garden of the Department of Botany, Jagannath University, Dhaka. Each pot was filled with $6.0 \mathrm{~kg}$ air-dried soil. Urea, triple super phosphate, muriate of potash and gypsum were applied at the rate of 2, 6, 6 and $3 \mathrm{~g}$ per pot respectively (recommended by BRRI). Cow dung $(0.5 \mathrm{~kg} /$ pot $)$ was also mixed homogeneously during the pot preparation. The pots of experiment was laid out in a randomized complete block design (RCBD) with five replications, each having 8 pots. Total number of pot was $200(5 \times 5 \times 8)$. Seeds of BRRI dhan- 44 were collected from Bangladesh Agricultural Development Corporation (BADC). Seeds were sterilized with $0.05 \%$ calcium hypochlorite solution and repeatedly washed in distilled water to remove any trace of chemicals before sowing. Seedlings were grown in earthen pots. Three seedlings (at 4-leaf stage) were transplanted to pot at the age of 40 days after sowing. Thinning was done in such a way that a healthy seedling of uniform size and vigour was allowed to grow. Irrigation was done as per necessity. Weeding was done twice at 18 and 40 days after transplanting (DAT). Split applications of urea were done twice at the rate of $2 \mathrm{~g}$ per pot at 24 and 54 DAT. The experiment consisted of five foliar treatments: 0 (control), 10, 25, 50 and 100 ppm TIBA. Treatments were applied at 32 DAT.

A total number of 10 plants ( 2 from each replication) was fixed from each treatment for data collection at definite interval except, destructive harvest, where, plants were collected from other pots. Data on leaf area (LA), leaf area ratio (LAR), specific leaf area (SLA), specific leaf weight (SLW), leaf area duration (LAD) and net assimilation rate (NAR) were recorded from the age of 10 days after spray (DAS) up to 40 DAS at an interval of 10 days. Crop growth rate (CGR), relative growth rate (RGR) and biomass duration (BMD) were recorded from the age of 0 DAS (date of foliar spray) to 60 DAS at an interval of 10 days. Leaf area was measured by length-width method (IRRI 1972). Growth parameters such as LAR, SLA, SLW, LAD, CGR, RGR and NAR were calculated using the classical growth analysis method (Radford 1967 and Hunt 1978). The BMD was calculated by using the formula of Sestak et al. (1971) Data were analyzed statistically and treatment means were compared by LSD test at 5\% level of significance (Steel and Torrie 1960). 


\section{Results and Discussion}

Leaf area per plant was found to increase following TIBA application at 10 DAS with an exception of $25 \mathrm{ppm}$, after that there was a progressive increase due to $10 \mathrm{ppm}$ only and varied significantly at 40 DAS (Table 1). Similar results of both increase and decrease was reported in Azuki bean with TIBA treatments (Yoshida et al. 1986). By applying NAA, both increase and decrease in LA per plant was also reported in BRRI dhan-29 and BRRI dhan 50 (Jahan and Adam 2011).

Table 1. Effect of TIBA on LA $\left(\mathrm{cm}^{2}\right)$, LAR $\left(\mathrm{g} \mathrm{cm}^{-2}\right)$ and SLA $\left(\mathrm{cm}^{2} \mathrm{~g}^{-1}\right)$ of BRRI dhan-44 at different days after spray.

\begin{tabular}{|c|c|c|c|c|c|c|c|c|c|c|c|c|}
\hline \multirow{3}{*}{$\begin{array}{l}\text { TIBA } \\
(\mathrm{ppm})\end{array}$} & \multirow[b]{3}{*}{10} & \multicolumn{3}{|c|}{ Leaf area (LA) } & \multicolumn{4}{|c|}{ Leaf area ratio (LAR) } & \multicolumn{4}{|c|}{ Specific leaf area (SLA) } \\
\hline & & \multicolumn{10}{|c|}{ Days after spray } & \multirow[b]{2}{*}{40} \\
\hline & & 20 & 30 & 40 & 10 & 20 & 30 & 40 & 10 & 20 & 30 & \\
\hline 0 & & & & & & & 4.68 & $3.62 \mathrm{a}$ & & & & \\
\hline 10 & 40.68 & 58.65 & 62.61 & $73.47 \mathrm{a}$ & 11.32 & $6.29 \mathrm{a}$ & 4.68 & $3.63 \mathrm{a}$ & $7.24 \mathrm{a}$ & $5.50 \mathrm{~d}$ & $a b$ & 8. \\
\hline 25 & 35.50 & 46.04 & 54.52 & $65.97 \mathrm{ab}$ & 11.46 & $5.00 \mathrm{ab}$ & 3.96 & $2.71 \mathrm{~b}$ & $23.93 \mathrm{a}$ & $8.79 \mathrm{c}$ & $7.89 \mathrm{bc}$ & $6.25 \mathrm{~b}$ \\
\hline 50 & 37.93 & 43.36 & 47.84 & $52.43 \mathrm{~b}$ & 10.08 & $4.35 \mathrm{~b}$ & 4.21 & $2.91 \mathrm{~b}$ & $15.07 \mathrm{~b}$ & $8.93 \mathrm{c}$ & $9.16 \mathrm{bc}$ & $10.12 \mathrm{a}$ \\
\hline 100 & 39.77 & 50.14 & 55.71 & $61.36 \mathrm{ab}$ & 8.45 & $4.29 \mathrm{~b}$ & 4.10 & $2.87 \mathrm{~b}$ & $16.71 \mathrm{~b}$ & $9.57 \mathrm{bc}$ & $8.96 \mathrm{bc}$ & $7.88 \mathrm{ab}$ \\
\hline $\operatorname{LSD}_{(0.05)}$ & NS & NS & NS & 16.33 & NS & 1.620 & NS & 0.697 & 4.28 & 3.55 & 2.01 & 2.74 \\
\hline
\end{tabular}

Mean in a vertical column followed by same letter or without letter do not differ significantly at 5 $\%$ level.

Results presented in Table 1 showed a gradual decreasing tendency in LAR all over the investigated period, where, $10 \mathrm{ppm}$ TIBA produced maximum value except at 30 DAS. Significant variations among the treatment means were observed at 20 and 40 DAS. Result also showed maximum LAR at the initial stage of vegetative growth then decreased gradually. This result is similar to the findings reported by Hossain et al. (2011).

Specific leaf area was significantly influenced following TIBA treatments. Plant receiving $10 \mathrm{ppm}$ TIBA resulted maximum value at 10 and 20 DAS, whereas, at 40 DAS it was similar to control. At the age of 30 DAS, maximum SLA was recorded from control which was statistically at par with $10 \mathrm{ppm}$ TIBA, whereas, other treatments responded negatively in majority of cases (Table 1). Literature regarding the effect of any growth regulators is limited on this trait and the probable reason of increased SLA might be the stimulating effect of this treatment on LA per plant and LAR.

The integration of weight and leaf area measurement over time provides value that is useful for studying the growth of crops (Shipley 2006). Results presented in Table 2 revealed that SLW was significantly influenced by TIBA application. The highest SLW 
was recorded from $25 \mathrm{ppm}$ treatment after 10 DAS. Here, application of $10 \mathrm{ppm}$ TIBA did not show positive response to SLW as responded in LA, LAR and SLA. In okra, SLW increased due to NAA $(20,40 \mathrm{ppm})$ and $\mathrm{GA}_{3}(25,50 \mathrm{ppm})$ application at 60 and 80 DAS, where, $1000 \mathrm{ppm}$ of miraculan treatment showed both positive and negative attitude at 60 DAS (Surendra et al. 2006).

Table 2. Effect of TIBA on SLW $\left(\mathrm{g} \mathrm{cm}^{-2}\right)$, LAD $\left(\mathrm{cm}^{2}\right.$ days $)$ and NAR $\left(\mathrm{gm}^{-2} \mathrm{day}^{-1}\right)$ of BRRI dhan44 at different days after spray.

\begin{tabular}{|c|c|c|c|c|c|c|c|c|c|c|}
\hline \multirow{3}{*}{$\begin{array}{l}\text { TIBA } \\
(\mathrm{ppm})\end{array}$} & \multicolumn{4}{|c|}{ Specific leaf weight (SLW) } & \multicolumn{3}{|c|}{$\begin{array}{c}\text { Leaf area Duration } \\
\text { (LAD) }\end{array}$} & \multicolumn{3}{|c|}{$\begin{array}{l}\text { Net assimilation rate } \\
\text { (NAR) }\end{array}$} \\
\hline & \multirow[b]{2}{*}{10} & \multirow[b]{2}{*}{20} & \multicolumn{5}{|c|}{ Days after spray } & \multirow[b]{2}{*}{$10-20$} & \multirow[b]{2}{*}{$20-30$} & \multirow[b]{2}{*}{$30-40$} \\
\hline & & & 30 & 40 & $10-20$ & $20-30$ & $30-40$ & & & \\
\hline 0 & $0.042 \mathrm{~b}$ & $0.085 \mathrm{~b}$ & $0.088 \mathrm{c}$ & $\begin{array}{c}0.117 \\
\text { bc }\end{array}$ & $4.05 \mathrm{c}$ & $5.58 \mathrm{ab}$ & $6.65 \mathrm{ab}$ & 1.488 & $\begin{array}{c}0.497 \\
\text { ab }\end{array}$ & 1.115 \\
\hline 10 & $0.037 \mathrm{~b}$ & $0.065 \mathrm{~b}$ & $\begin{array}{c}0.095 \\
b c\end{array}$ & $\begin{array}{c}0.112 \\
\mathrm{bc}\end{array}$ & $4.97 \mathrm{a}$ & $6.06 \mathrm{a}$ & $6.81 \mathrm{a}$ & 1.189 & $\begin{array}{l}0.665 \\
a b\end{array}$ & 1.072 \\
\hline 25 & $0.042 \mathrm{~b}$ & $0.115 \mathrm{a}$ & $0.130 \mathrm{a}$ & $0.161 \mathrm{a}$ & $4.08 \mathrm{c}$ & $5.03 \mathrm{bc}$ & $5.99 \mathrm{bc}$ & 1.634 & $1.015 \mathrm{a}$ & 2.132 \\
\hline 50 & $0.067 \mathrm{a}$ & $0.114 \mathrm{a}$ & $0.116 \mathrm{a}$ & $0.100 \mathrm{c}$ & $4.06 \mathrm{c}$ & $4.54 \mathrm{c}$ & $5.01 \mathrm{~d}$ & 1.564 & $0.319 \mathrm{~b}$ & 1.069 \\
\hline 100 & $0.062 \mathrm{a}$ & $\begin{array}{c}0.106 \\
\mathrm{ab}\end{array}$ & $0.112 b$ & $\begin{array}{l}0.135 \\
\mathrm{ab}\end{array}$ & $4.59 \mathrm{~b}$ & $5.29 \mathrm{~b}$ & $5.82 \mathrm{bc}$ & 1.600 & 0.781 & 1.285 \\
\hline $\operatorname{LSD}_{(0.05)}$ & 0.015 & 0.028 & 0.017 & 0.033 & 0.151 & 0.550 & 0.660 & NS & 0.541 & NS \\
\hline
\end{tabular}

Mean in a vertical column followed by same letter or without letter do not differ significantly at 5 $\%$ level.

Findings of the experiment revealed that foliar application of TIBA significantly affected LAD throughout the investigated period (Table 2). The LAD is a useful concept not only in depicting the efficiency of photosynthetic system but also in showing a linear relationship with dry matter accumulation (Chetti and Shirohi 1995). Significantly highest LAD was obtained from 10 ppm treatment at 10-20 and also during 20-30 and 30-40 DAS, although the statistically at par with control. At initial sampling date, LAD increased due to all treatments. Foliar application of NAA, $\mathrm{GA}_{3}$ and miraculan had stimulatory effects on LAD in okra (Surendra et al. 2006).

Table 2 showed that the maximum NAR was obtained from 25 ppm TIBA treatment, which was significantly higher than $50 \mathrm{ppm}$ at the period of 20-30 DAS. Application of $100 \mathrm{ppm}$ TIBA also showed higher NAR, whereas, 10 and $50 \mathrm{ppm}$ responded rather negatively. NAR measures the mean photosynthetic efficiency of leaves in a crop community. Both increase and decrease in NAR using other growth regulator is available in rice (Jahan and Adam 2011). 
Results presented in Table 3 showed that TIBA had stimulating effects on CGR all over the growing periods but not significantly in most of the sampling dates. Significantly higher CGR values were obtained at the initial and final sampling periods and that was due to application of highest rate of TIBA i.e. $100 \mathrm{ppm}$ TIBA. Treatments showed a general increase in CGR with increasing concentration of TIBA up to the highest concentration used except at 10-40 DAS due to $50 \mathrm{ppm}$. Report on the effects of any growth regulator on this aspect is not available.

Table 3. Effect of TIBA on crop growth rate $\left(\mathrm{g} \mathrm{day}^{-1}\right)$ and relative growth rate $\left(\mathrm{g} \mathrm{g}^{-1} \mathrm{plant}^{-1}\right)$ of BRRI dhan-44 at different days after spray.

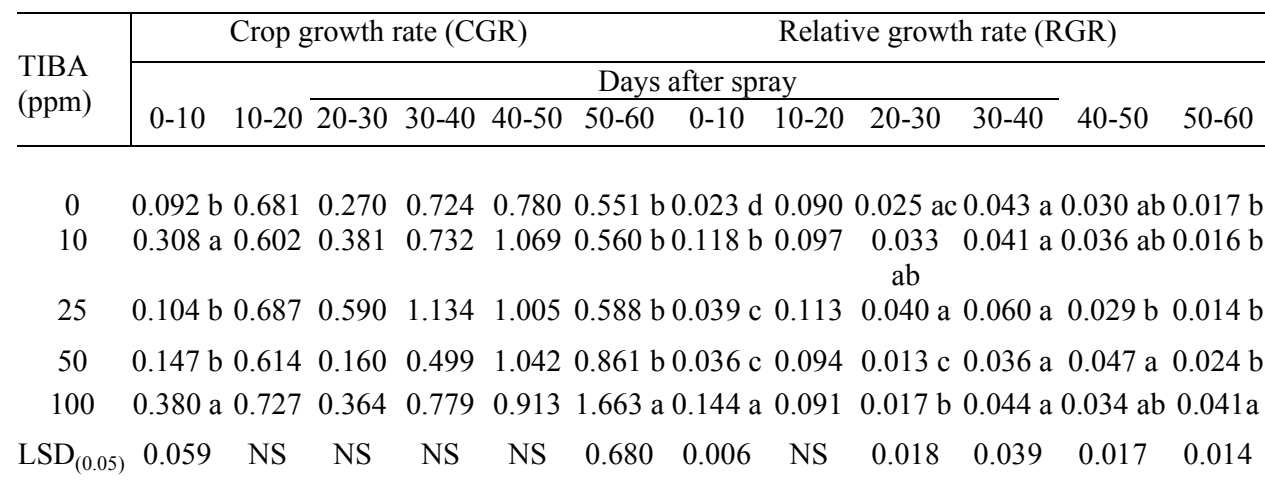

Mean in a vertical column followed by same letter or without letter do not differ significantly at 5 $\%$ level.

The RGR affected significantly following TIBA treatments in most of the sampling dates. Significantly maximum value was obtained from $100 \mathrm{ppm}$ at 0-10 DAS, after that the maximum was recorded from $25 \mathrm{ppm}$ up to 30-40 DAS, where it was statistically identical to other treatments. After the growth period of 30-40 DAS, RGR decreased gradually in most cases and at 40-50 DAS, the maximum was obtained from $50 \mathrm{ppm}$ TIBA which was significantly different from $25 \mathrm{ppm}$ whereas, highest concentration of TIBA produced significantly maximum RGR at 50-60 DAS (Table 3). Higher RGR at the initial stages of the growth was also reported in rice with NAA (Jahan and Adam 2011). It has been suggested that the decrease in RGR could be attributed to shading of lower leaves by upper leaves (Thorne 1961).

Foliar application of TIBA had significant response on BMD of BRRI dhan-44 all over the growth stages. Application of TIBA did not show positive attitude in most cases at early phases. After that phase (10-20 DAS) higher BMD was obtained from all treatments except $50 \mathrm{ppm}$, where, it was increased at 50-60 DAS only. Significantly maximum BMD was recorded from 100 ppm treatment at 10-20 and 20-30 DAS, after 
that $25 \mathrm{ppm}$ TIBA resulted significantly highest BMD even though at par with $100 \mathrm{ppm}$ at 50-60 DAS (Table 4). The probable reasons of higher BMD might be due to the production of higher SLW and better CGR and RGR in most of the growth stages.

Table 4. Effect of TIBA on biomass duration $\left(\mathrm{g} \mathrm{day}^{-1}\right)$ at different days after spray and on plant height $(\mathrm{cm})$, number of tillers and grain yield $(\mathrm{g})$ per plant of BRRI dhan- 44 .

\begin{tabular}{|c|c|c|c|c|c|c|c|c|c|}
\hline \multirow{3}{*}{$\begin{array}{l}\text { TIBA } \\
(\mathrm{ppm})\end{array}$} & \multicolumn{6}{|c|}{ Biomass duration (BMD) } & $\begin{array}{l}\text { Plant } \\
\text { height }\end{array}$ & $\begin{array}{c}\text { Tillers/ } \\
\text { plant }\end{array}$ & $\begin{array}{l}\text { Yield/ } \\
\text { plant }\end{array}$ \\
\hline & \multicolumn{6}{|c|}{ Days after spray } & \multirow{2}{*}{\multicolumn{3}{|c|}{ At harvest }} \\
\hline & $0-10$ & $10-20$ & $20-30$ & $30-40$ & $40-50$ & $50-60$ & & & \\
\hline 0 & $36.09 \mathrm{a}$ & $74.06 \mathrm{~b}$ & $120.94 \mathrm{~b}$ & $170.71 b c$ & $245.98 \mathrm{bc}$ & $312.58 \mathrm{~b}$ & 105.85 & 24.43 & 13.16 \\
\hline 10 & $27.64 \mathrm{~b}$ & $73.19 b$ & $122.41 \mathrm{c}$ & $178.11 \mathrm{~b}$ & $268.18 \mathrm{~b}$ & $349.64 \mathrm{~b}$ & 112.72 & 30.57 & 38.03 \\
\hline 25 & $28.20 \mathrm{~b}$ & $67.78 \mathrm{~b}$ & $131.65 \mathrm{~b}$ & $217.89 \mathrm{a}$ & $324.85 \mathrm{a}$ & $404.04 \mathrm{a}$ & 107.25 & 29.00 & 31.60 \\
\hline 50 & $36.40 \mathrm{a}$ & $74.48 \mathrm{~b}$ & $113.24 \mathrm{c}$ & $146.21 \mathrm{c}$ & $223.28 \mathrm{c}$ & $318.43 \mathrm{~b}$ & 108.47 & 27.00 & 28.37 \\
\hline 100 & $32.90 \mathrm{ab}$ & $88.26 \mathrm{a}$ & $136.88 \mathrm{a}$ & $186.34 \mathrm{~b}$ & $271.00 \mathrm{~b}$ & $398.70 \mathrm{a}$ & 107.69 & 29.43 & 25.34 \\
\hline $\operatorname{LSD}_{(0.05)}$ & 7.36 & 12.62 & 12.22 & 30.41 & 32.12 & 40.72 & NS & NS & NS \\
\hline
\end{tabular}

Mean in a vertical column followed by same letter or without letter do not differ significantly at 5 $\%$ level.

Table 4 also revealed that application of TIBA had stimulatory effect on plant height, number of tillers and grain yield per plant of BRRI dhan-44. The tallest plant and maximum number of tillers per plant was obtained from $10 \mathrm{ppm}$ TIBA but, statistically non-significant. Yield per plant obtained from 0, 10, 25, 50 and $100 \mathrm{ppm}$ were 13.16, $38.03,31.60,28.37$ and $25.34 \mathrm{~g}$, respectively. The probable reasons of increased yield following all treatments might be due to the affirmative effect of TIBA on number of tillers per plant, which plays positive role on the number of panicles and other yield contributing characters of rice. The maximum yield was also obtained from $10 \mathrm{ppm}$ followed by 25,50 and 100 ppm TIBA respectively.

The overall results of this investigation indicated that TIBA has both stimulatory and inhibitory effect on different growth parameters and the magnitude of effect was relatively different depending on the concentration. Findings of the experiment are in accord with the fact that plant growth regulators at identical concentration can have quite different effects on different plants and even on different organs of the same plant (Ridge 1991). Out of the five concentrations, $10 \mathrm{ppm}$ TIBA produced better stimulations in both growth and yield.

\section{References}

Abdelgadir, H. A., S. D. Johnson and J. Van Staden. 2009. Promoting branching of a potential biofuel crop Jatropha curcas L. by foliar application of plant growth regulators. Plant growth regulation. 58(3): 287-295. 
Chetti, M. B. and G. S. Sirohi. 1995. Effect of water stress on leaf characterstics and its recovery in mungbean (Vigna radiata (L.) Wilczek) cultivars. J. Maharashtra Agric.Univ. 20(3): 8587.

Djanaguiraman, M., J. A. Sheeba, D. D. Devi and U. Bangarusamy. 2005. Response of cotton to atonik and TIBA for growth, enzyme and yield. J. Biol. Sci. 5(32): 158-162.

Hossain, M. A., M. A. R. Sarkar and S. K. Paul. 2011. Growth analysis of late transplant Aman rice (cv. BR23) raised from tiller seedlings. Libyan Agric. Res. Center J. Int. 2(6): 265-273.

Hunt, R. 1978. The fitted curve in plant growth studies. In: Math and Plant Physiology (Eds. D. A. Rose and D. A. C. Edwas). Aca. Press.

IRRI. 1972. Annual Report. Int. Rice Res. Inst., Los Banos, Laguna, Philippines. p. 238

Jahan, N. and A. M. M. G. Adam. 2011. Comparative growth analysis of two varieties of rice following naphthalene acetic acid application. Bangladesh J. Acad. Sci. 35(1): 113-120.

Kler, D. S. and G. S. Dhillon. 1993. Effect of cycocel and TIBA spray on the pod yield of groundnut. Environment and Ecology. 11(2): 475.

Lampe, K. 1995. Rice research: food for billion people. Ann. Rev. Plant Physio. p. 235.

Mondal, M. M. A. and R. K. Dutta. 2002. Effect of TIBA (2,3,5-Triiodobenzoic acid) on growth and yield of tomato. J. Agricul. Res. 40(3-4): 273-279.

Phillips, J. C. and D. O. Chilcote. 1981. Growth and reproductive development of alfalfa as influenced by 2,3,5-triiodobenzoic acid. Canadian J. Bot. 59: 373-376.

Radford, P. S. 1967. Growth analysis formulae, their use and abuse. Crop Sci. 7: 171-175.

Rahman, M. A. and M. M. Rahman. 1997. Effect of maleic hydrazide and tri-iodo benzoic acid on growth, sex expression and yield of Lagenaria siceraria (Mol.) Standl. J. Asiat. Soc. Bangladesh, Sci. 23(2): 172-178.

Ravichandran, V. K. and C. Ramaswami. 1991. Effect of TIBA on yield and yield components of soybean in different seasons. Haryana J. Agron. 7(2): 120-122.

Ridge, I. 1991. Plant cells and growth. In: Plant physiology. The Open University, Hodder and Stoghton. U.K. pp. 225-281.

Sestak, Z., J. Catsky and P. G. Jarris. 1971. Plant synthesis. In: Production Manual of Methods, N.V. Publication. pp. 343-381.

Shipley, P. 2006. Net assimilation rate, specific leaf area and leaf mass ratio: which is most closely correlated with relative growth rate, A meta-analysis. Fun. Ecol. 20: 565-574.

Steel, R. G. D. and J. H. Torrie. 1960. Principles and Procedures of statistics. McGraw- Hill, New York. pp. 480-482.

Surendra, P., C. M. Nawalagatti, M. B. Chetti and S. M. Hiremath. 2006. Effect of plant growth regulators and micronutrients on morpho-physiological and biochemical traits and yield in Okra. Karnataka J. Agric. Sci.19(3): 694-697.

Thorne, G. N. 1961. Effects of age and environment on net assimilation rate of barley. Ann. Bot. 25: 29-38.

Wilson, W. J. 1981. Analysis of growth, photosynthesis and light interception for single plant stand. Ann. Bot. 48: 507-512.

Yoshida, K., A. Bando, K. Yanagisawa and K. Gotoh. 1986. Effects of TIBA (2,3,5 tri-iodo benzoic acid) on growth and yield of Azuki bean, Vigna anguilaris. Japan J. Crop Sci. 55(3): 345-351. 